\title{
Larangan Risywah Pada Penerapan Etika Bisnis Islam Di Perbankan Syariah
}

Oleh: Aisyah Sumayyah

\author{
Rachmad Rizqy Kurniawan Ph.D
}

\begin{abstract}
Abstrac
This article discusses examples of cases related to the rules of ma harrama fi'luhu harrama thalbuhu (what is forbidden to do, it is also forbidden to seek). Among the cases related to this rule are risywah, namely bribery, in Islam it is called arriswah which means fulfilling one's intentions (its interests) by persuading. The word Ar-Riswah comes from the word Arrisa'i which means a rope that conveys a bucket to the water. Bribery activities even though they are known to be unlawful, people are still intensively carried out, such as people to get a job or achieve legal victory, alighting to put children in Educational institutions cannot be separated from the practice of bribing bribes, even though it is clear that Rasulullah SAW cursed those who bribed or Riswah.
\end{abstract}

Keywords : Risywah, bribery, illegal

\begin{abstract}
Abstrak
Artikel ini membahas tentang contoh perkara terkait dengan kaidah ma harrama fi'luhu harrama thalbuhu ( apa yang diharamkan untuk dilakukan, diharamkan pula untuk dicari ). Diantara perkara terkait kaidah tersebut adalah pada risywah yakni Suap menyuap, dalam islam di sebut ar- riswah yang artinya adalah memenuhi hajat dengan (kepentingannya) dengan membujuk. Kata Ar- Riswah berasal dari kata Ar- risa'i yang berarti tali yang menyampaikan timba ke air.Kegiatan suap menyuap kendati diketahui keharamannya namun tetap saja gencar dilakukan orang-orang, seperti orang untuk meraih pekerjaan atau meraih kemenangan hukum hinggap untuk memasukkak anak ke lembaga pendidikan tak lepas dari praktek suap menyuap, Padahal sudah jelas-jelas bahwasannya Rosulullah SAW melaknat orang-orang yang suap menyuap atau Riswah.
\end{abstract}

Kata Kunci : Risywah, Suap Menyuap, Haram

\section{Pendahuluan}

Perbankan syariah dikembangkan sebagai sebuah alternatif bagi praktik perbankan konvensional. Kritik terhadap bank konvensional oleh konsep perbankan syariah bukanlah menolak bank dalam fungsinya sebagai lembaga intermediasi keuangan melainkan dalam karakteristik kegiatan bank konvensional masih terdapat unsur riba, judi (maysir), ketidakpastian (gharar), dan bathil. Dengan dilarangnya riba, risywah, maysir, gharar, dan bathil dalam transaksi perbankan maka sebagai gantinya dapat menerapkan akal, agama, harta, 
dan keturunan umat Islam dari transaksi yang diharamkan oleh syariat Islam, khususnya transaksi dalam bidang perbankan. Keberadaan industri perbankan syariah yang menjunjung tinggi prinsip etika bisnis Islam adalah mutlak diperlukan sebagai fasilitator transaksi yang halal menurut syariat Islam.

Allah membuat hidup ini sempura dan memiliki tujuan yang luar biasa untuk semua, dalam rutinitas sehari-hari ini setiap makhluk memiliki penghibur dalam menjalankannya, manusia dijadikan oleh Allah SWT sebagai makhluk yang ideal atas Ciptaannya memiliki keinginan, kemampuan pola pikir untuk menjalankan kehidupan ini. Manusia sendiri memiliki aktivitas di semua bagian kehidupan, termasuk dalam aktivitas keuangan untuk melanjutkan kehidupan ini dengan sejahtera dan bahagia.

Dalam hidup ini menjaga perekonomian dengan perbisnisan, perdagangan dan menyelesaikan aktivitas sosial. Itulah sebabnya orang menyelesaikan kegiatan ekonomi dengan sukses dan cakap untuk memperoleh manfaat dan memberikan tindakan yang unggul untuk membuat daya tarik ketika melakukan transaksi dan pemberian kepada masyarakat umum.

Dalam menjalankan bisnis, seorang manajer keuangan harus memiliki moral yang tertanam dalam bisnisnya dengan memberikan kegiatan ekonomi yang tekun, disiplin dan tak kenal lelah dalam bekerja sama untuk menawarkan beberapa insentif yang mendorong perusahaan dalam perspektif lokal baik segi produksi, dan lain-lain. untuk membuat perusahaan yang unggul dan sinergis.

Mengungkapkan etika bisnis Islam merupakan proses mengetahui hal- hal yang benar dan yang salah dalam pandangan Islam berkaitan dengan produk dan pelayanan perusahaan bagi yang membutuhkan. Pelaku penelitian memberikan kesimpulan yang di dalam nya bahwasanya agama Islam memiliki peraturan berdasarkan Al Quran dan hadist Rasulullah SAW yang memberikan atas perintah yang wajib dilaksanakan umat manusia di muka bumi yang mengatur segala aspek kehidupan ini baik itu kesehatan, politik, dan sebagainya. ${ }^{1}$

Bangsa negeri Indonesia ini memiliki kekayaan yang sangat amat berlimpah dan memiliki kuantitas penduduk Islam yang terpesat di seluruh dunia. Menurut Noor dan Ahmad (2012), bank syariah modern pertama kali didirikan di Mesir pada tahun 1963 dan sejak saat itu telah berdiri lebih dari 300 institusi di lebih dari 75 negara. ${ }^{2}$ Industri perbankan syariah berkembang pesat dan semakin populer di seluruh dunia, termasuk di Indonesia. Di Indonesia, industri perbankan syariah dipelopori oleh Bank Muamalat Indonesia yang berdiri pada tahun 1991 yang diprakarsai oleh Majelis Ulama Indonesia (MUI), Ikatan Cendekiawan Muslim Indonesia (ICMI), sekelompok pengusaha Muslim, dan Pemerintah Indonesia. Bank Muamalat Indonesia mulai melakukan operasi secara resmi pada bulan Mei 1992 setelah adanya Undang-Undang Perbankan No. 7 Tahun 1992 yang mengatur tentang izin pengoperasian perbankan dengan prinsip syariah. Untuk mempercepat perkembangan perbankan syariah di Indonesia, maka pemerintah memutuskan menerapkan sistem perbankan ganda (dual banking system) sehingga selain bank syariah murni, bank konvensional juga diberikan kesempatan untuk memberikan layanan syariah melalui mekanisme islamic window dengan membentuk Unit Usaha Syariah.

\footnotetext{
${ }^{1}$ Abdul Aziz, Etika Bisnis Perspektif Islam, Bandung: Alfabeta, Cet. 1. 2013

2 Noor, M.A.N.M., and N.H.B. Ahmad. (2012) “The Determinants of Islamic Banks' Efficiency Changes: Empirical Evidence from the World Banking Sectors." Global Business Review, 13 (2): 179-200. doi:10.1177/097215091201300201. http://gbr.sagepub.com/cgi/doi/10.11 77/097215091201300201.
} 
Terciptanya bank syariah ini dari bank konvensional memberikan kekuatan di dunia ekonomi moneter di Indonesia. Bank syariah dengan bank konvensional ini melaksanakan kinerja nya berbeda- beda satu sama lainnya baik itu akad, dan kinerja transaksinya. Bank Syariah ini memiliki cara melaksanakan transaksi dengan menggunakan Nisbah, cara ini guna menghindari transaksi yang dilarang Allah SWT yang berlandasan dengan Al Quran dan Hadist Rasulullah SAW. Bank Syariah ini dijalankan untuk mensejahterakan masyarakat dengan melaksanakan transaksi tidak menggunakan bunga baik melaksanakan transaksi jual maupun beli.

Bank Syariah ini melaksanakan transaksi dengan nasabah dengan landasan Al Quran dan Hadist Rasulullah SAW yang menggunakan fatwa dari DSN-MUI (Dewan Syariah Nasional) dan bank syariah ini di berikan pengawasan dari DPS (Dewan Pengawas Syariah). Di BSM (Bank Mandiri Syariah) telah berdiri sejak 1 November 1999. Di dalam Islam telah diatur untuk kehidupan di dunia baik itu dengan jual beli, bersosial dan sebagainya di dunia dan akhirat.

Di Indonesia negara yang penuh dengan keragaman perbedaan baik itu perbedaan agama, budaya, dan sebagainya maka sebab itu bangsa Indonesia mempertimbangkan semuanya dalam melaksanakan kegiatan baik itu kegiatan ekonomi dan lainnya dengan ini dilaksanakan dengan semestinya melakukan toleransi satu sama lainnya. Di Indonesia masih menganut bank yang berprinsip konvensional yang melaksanakan kegiatan perbankan dengan menggunakan bunga. Prinsip bunga ini memiliki perubahan saat melaksanakan transaksi kredit yang mengalami naik maupun turun yang dapat mengakibatkan kemunduran pada pembayaran transaksi.

Penerapan prinsip etika bisnis Islam dalam praktik perbankan syariah merupakan persyaratan mutlak yang harus dipenuhi menurut tuntunan syariat agama Islam dan sebagai identitas pembeda antara bank syariah dengan bank konvensional sehingga apabila perbankan syariah tidak menerapkan prinsip etika bisnis Islam secara memadai maka akan kehilangan nilai lebih yang dimilikinya bila dibandingkan dengan bank konvensional, dan pada akhirnya dapat mengancam kelangsungan hidup perbankan syariah di masa depan. Mengingat urgensi penerapan prinsip etika bisnis Islam pada industri perbankan syariah, maka tujuan penelitian ini adalah mencoba merumuskan bagaimanakah larangann risywah dalam penerapan etika bisnis Islam di perbankan syariah, tantangan penerapan etika bisnis Islam di perbankan syariah, dan tindakan untuk mengatasi tantangan tersebut.

\section{Rumusan Masalah}

Bagaimana larangan risywah pada penerapan etika bisnis di perbankan syariah?

\section{Tujuan Penelitian}

Untuk mengetahui Bagaimana larangan risywah pada penerapan etika bisnis di perbankan syariah?

\section{Pembahasan}

\section{Pengertian Risywah}

Pengertian risywah menurut etimologis berasal dari bahasa Arab رشا" "يرشو yang masdar رشوة huruf ra-nya dibaca kasrah, fathah atau dhammah ) berarti الجعل yaitu upah, hadiah, komisi atau 
suap. ${ }^{3}$ Risywah atau sogok merupakan penyakit (patologi) sosial atau tingkah laku yang menyimpang dalam kehidupan bermasyarakat dan tidak dibenarkan oleh ajaran Islam. Sedangkan risywah menurut istilah adalah praktik pemberian uang atau barang atau imingiming sesuatu kepada masa (voters) secara berkelompok atau individual, untuk mendapatkan keuntungan politis (political again). Artinya tindakan money politic itu dilakukan secara sadar oleh pelakunya. ${ }^{4}$

Di dalam al Mujam al Wasith disebutkan bahwa makna risywah adalah: ما"عطى لقضاء مطلحت

$$
\text { إبطال حق أو ما"عطى إلحقاق باطل أو }
$$

"Apa saja yang diberikan (baik uang maupun hadiah) untuk mendapatkan suatu manfaat atau segala pemberian yang bertujuan untuk mengukuhkan sesuatu yang batil dan membatilkan suatu yang haq"

Menurut Ali bin Muhammad as-Sayyid as-Syarif al-Jurjani, risywah adalah sesuatu pemberian yang diberikan kepada seseorang untuk membatalkan sesuatu yang hak (benar) atau membenarkan yang batil. Sedangkan menurut ulama yang lain, risywah adalah sesuatu pemberian yang menjadi alat bujukan untuk mencapai tujuan tertentu. ${ }^{5}$

Menurut undang-undang republik Indonesi No. 11 tahun 1980 tentang tindak pidana suap, suap didefenisikan sebagai memberi atau menjanjikan sesuatu kepada seseorang dengan maksud untuk menbujuk supaya orang itu berbuat sesuatu atau tidak berbuat sesuatu dalam tugasnya yang berlawanan dengan kewenangan atau kewajiban yang menyangkut kepentingan umum. ${ }^{6}$

Risywah merupakan kejahatan yang dilarang dalam Islam begitu juga tindakan tercela dalam kehidupan manusia. Dikatakan kejahatan karena memang di dalam prakteknya sarat dengan manipulasi dan kezhaliman terhadap sesama. Di dalam al Qur"ean terdapat empat ayat yang berkaitan langsung dengan risywah. Rincian dari ayat tersebut yaitu satu ayat terdapat di surat Al-Baqarah dan tiga ayat terdapat di surat AlMaidah.

Surah Al-Baqarah : 188

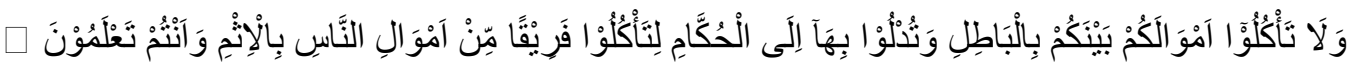

Artinya : "Dan janganlah kamu makan harta diantara kamu dengan dengan jalan yang batil, dan jangalah kaumu menyuap dengan harta itu kepada para hakim, dengan maksud agar kamu dapat memakan sebagian harta orang lain itu dengan jalan dosa, padahal kamu mengetahui. ،7

\section{Etika Bisnis}

Etika adalah kaidah atau seperangkat prinsip yang mengatur hidup manusia, yang merupakan bagian dari filsafat yang membahas secara rasional dan kritis tentang norma atau moralitas.

\footnotetext{
${ }^{3}$ Ahmad Warson Munawwir, h. 501

${ }^{4} 2$ Indra Ismawan, Money Politic Pengaruh Uang Dalam Pemilu, (Yogyakarta : Penerbit Media Presindo, 1999), h. 4.

${ }^{5}$ Abdul Aziz Dahlan, Ensiklopedi Hukum Islam, (Jakarta : Intermasa, 1996), h. 1506

${ }^{6}$ Tim Penyusun Undang-Undang Republik Indonesia, Tindak Pidana Suap, www.pih.deplu.go.id, diakses $17 / 02 / 2013$.

73 Departemen Agama Republik Indonesia, al-Quran dan Terjemahnya, (Semarang, CV. Syifa' Semarang: 1998), h. 23.
} 
Dengan demikian, etika berbeda dengan moral. Etika adalah refleksi kritis dan penjelasan rasional mengapa sesuatu itu baik atau buruk, sedangkan norma adalah suatu pranata dan nilai mengenai baik dan buruk. ${ }^{8}$

Etika bisnis dapat diartikan etika yang diaplikasikan pada kegiatan bisnis. ${ }^{9}$ Etika bisnis dapat diartikan juga sebagai aturan tingkah laku dalam pengambilan keputusan bisnis. ${ }^{10}$ dan dalam rangka memenuhi harapan masyarakat dari kegiatan bisnis. ${ }^{11}$ Oleh karenanya, Donaldson (1982) menyatakan bahwa bisnis memiliki kewajiban moral untuk memproduksi barang dan jasa secara efisien demi kesejahteraan masyarakat, bukan hanya sekedar mengejar keuntungan semata. $^{12}$

\section{Etika Bisnis Dalam Islam}

Etika bisnis Islam mengajarkan bahwa laba yang diperbolehkan harus sesuai dengan hukum nasional maupun syariah yang berlaku, serta tingkat laba tidak menjurus pada eksploitasi, gangguan fungsi pasar, dan kejahatan sehingga penetapan harga yang berlebihan sehingga merugikan masyarakat jelas tidak diperkenankan. ${ }^{13}$

Secara umum, prinsip etika bisnis Islam harus memenuhi persyaratan sebagai berikut: ${ }^{14}$

- Akidah

Dengan adanya penyerahan diri kepada Allah Ta'ala maka pelaku bisnis akan selalu menjaga perbuatannya dari hal-hal yang dilarang oleh syariah

- Shidiq

Sifat shiddiq mendorong rasa tanggung jawab atas segala perbuatan dalam hal muamalah.

- Fathanah

Sifat fathanah ini mendorong kearifan berpikir dan bertindak sehingga keputusan yang dihasilkan menunjukkan profesionalisme yang didasarkan sikap akhlak seperti akhlak Rasulullah Saw.

- Amanah

Hubungan bisnis yang dilandasi kejujuran memunculkan kepercayaan yang merupakan hal paling mendasar dari semua hubungan bisnis.

- Tabligh

Kemampuan berkomunikasi dalam kata tabligh menunjukkan proses menyampaikan sesuatu untuk mempengaruhi orang lain melalui perkataan yang baik.

\footnotetext{
${ }^{8}$ Rivai, Veithzal; Nuruddin, Amiur; Arfa, Faisar Ananda (2012) Islamic Business and Economic Ethics: Mengacu pada Al-Quran dan Mengikuti Jejak Rasulullah SAW dalam Bisnis, Keuangan, dan Ekonomi. Jakarta: Bumi Aksara

${ }^{9}$ Chryssides GD, and Kaler JH. (1993) An Introduction to Business Ethics. London: Chapman and Hall

${ }^{10}$ Jones I, and Pollitt M. (1998) Introduction. In: Jones I, Pollitt M. (Ed.) The Role of Business Ethics in Economic

Performance. London: MacMillan Press

${ }^{11}$ Grace D, and Cohen S. (1995) Business Ethics. Melbourne: Oxford University Press

12 Donaldson T. (1982). Constructing a Social Contract for Business. In: Donaldson T. (Ed.) Corporations and Morality. Englewood Cliffs: Prentice-Hall

${ }^{13}$ Basah, MYA, and MM Yusuf. (2013) "Islamic Bank and Corporate Social Responsibility (CSR)." European Journal of Business and Management, 5 (11): 194-209. http://iiste.org/Journals/index.php/EJ BM/article/view/5441.

${ }^{14}$ Qardhawi, Yusuf. (2001) Peran Nilai dan Moral Dalam Perekonomian Islam. Jakarta: Rabbani Press.
} 
- Tidak melakukan praktik bisnis yang bertentangan dengan syariah, antara lain produk dan jasa yang dijual haram, gharar, al-gabn dan tadlis, riba, ikhtikar, mengurangi timbangan dan risywah.

Etika bisnis Islam menegaskan bahwa segala kegiatan ekonomi harus tunduk kepada etika, dan bukan sebaliknya. Nilai-nilai etika bisnis Islam seharusnya tercermin dalam segala aspek kegiatan bisnis sesuai nilai moralitas dan spiritualitas sehingga akan meningkatkan pandangan hidup Islami. ${ }^{15}$. Haniffa dan Hudaib (2007) menyatakan bahwa jasa keuangan syariah semestinya menjunjung tinggi nilai etika bisnis Islam sebab memiliki filosofi bertingkahlaku etis dengan mempromosikan keadilan dan kesejahteraan dalam masyarakat dan mencari ridho Ilahi. $^{16}$

\section{Larangan risywah pada penerapan etika bisnis islam di perbankan syariah}

Fatwa yang ditetapkan oleh DSN MUI disahkan oleh pemerintah menjadi peraturan perundangundangan, contohnya antara lain adalah Undang-Undang Republik Indonesia No. 21 Tahun2008 tentang Perbankan Syariah yang menyatakan bahwa kegiatan yang berlandaskan prinsip syariah adalah kegiatan usaha yang tidak mengandung unsur sebagai berikut (Guza, 2008) :

a. Riba, yaitu penambahan pendapatan secara bathil/tidak sah antara lain transaksi pertukaran barang yang tidak sama kualitas, kuantitas, dan waktu penyerahan (fadhl), atau dalam transaksi pinjam-meminjam yang memberikan syarat nasabah penerima fasilitas mengembalikan dana yang diterima melebihi pokok pinjaman karena berjalannya waktu (nasi'ah);

b. Maisir, yaitu transaksi yang digantungkan kepada suatu keadaan yang tidak pasti dan bersifat untung-untungan.

c. Gharar,yaitu transaksi yang objeknya tidak jelas,tidak dimiliki, tidak diketahui keberadaannya, atau tidak dapat diserahkan kecuali diatur lain dalam syariah.

d. Haram, yaitu transaksi yang objeknya dilarang dalam syariah;

e. Zalim, yaitu transaksi yang menimbulkan ketidakadilan bagi pihak lainnya. ${ }^{17}$

Larangan risywah dalam penerapan etika bisnis islam di perbankan syariah jelas karena dua unsur fatwa yang merupakan prinsip syariah dari perbankan syariah terkandung dalam risywah yakni haram dan zalim .

\footnotetext{
${ }^{15}$ Naqvi SNH. (1981) Ethics and EconomicsAn Islamic Synthesis. Leicester: The Islamic Foundation.

${ }^{16}$ Haniffa, Oszaini; and Hudaib, Mohammad (2007) "Exploring the Ethical Identity of Islamic Banks via Communication in Annual Reports". Journal of Business Ethics,76:97-116.

17 Guza, Afnil (2008) Himpunan Undang-undang Perbankan Republik Indonesia, UU RI Nomor 21 Tahun 2008 Perbankan Syariah, UU RI nomor 10 Tahun 1998 Perbankan, UU RI Nomor 3 Tahun 2004 Bank Indonesia.Jakarta: Asa Mandiri
} 


\section{Kesimpulan}

Riswah merupakan kejahatan publik (jarimatul a'amah) yang telah membudaya dan biasa di negeri kita. Membudaya karena menjadi suatu hal yang biasa di banyak lini kehidupan masyarakat dari kelas pejabat sampai kelas rakyat. Selain itu risywah dianggap lumrah karenabanyak orang yang melakukukannya. Saat ini banyak orang yang tidak peduli melakukan risywah dalam transaksi, pekerjaan bahkan dalam hukum demi kepentingan pribadi atau kelompok. Mereka berasumsi hal tersebut sah-sah saja bahkan dianggap sebagai rezeki yang halal untuk dinikmati. Mafia di negeri inibisa kebal hukum karena uang suap yang menyumpal mulut para hakim yang doyan memakan harta haram. Bahkan, budaya KKN di negeri ini menjadi subur karena ditopang dengan budaya suap-menyuap/ risywah yang telah mengakar kuat.

Penerapan prinsip etika bisnis Islam dalam perbankan syariah yang sesuai dengan syariat, fiqih, maupun siyasah sangat penting dalam rangka menciptakan kemaslahatan umat yang merupakan tujuan pendirian perbankan syariah. Penyimpangan terhadap prinsip etika bisnis syariah akan menimbulkan ketidakselarasan dengan cita-cita syariat agama Islam dan mengancam kelangsungan hidup bank syariah itu sendiri. Sayangnya masih banyak tantangan yang harus dihadapi dalam penerapan prinsip etika Islam dalam perbankan syariah sehinggadibutuhkan sinergi para pemangku kepentingan(stakeholder) baik eksternal maupun internal dalam mengatasi berbagai tantangan tersebut. 


\section{Daftar pustaka}

Abdul Aziz, Etika Bisnis Perspektif Islam, Bandung: Alfabeta, Cet. 1. 2013

Noor, M.A.N.M., and N.H.B. Ahmad. (2012) "The Determinants of Islamic Banks' Efficiency Changes: Empirical Evidence from the World Banking Sectors." Global Business Review, 13 (2): 179-200.

doi:10.1177/097215091201300201. http://gbr.sagepub.com/cgi/doi/10.11 77/097215091201300201.

Ahmad Warson Munawwir, h. 501

2 Indra Ismawan, Money Politic Pengaruh Uang Dalam Pemilu, (Yogyakarta : Penerbit Media Presindo, 1999), h. 4.

Abdul Aziz Dahlan, Ensiklopedi Hukum Islam, (Jakarta : Intermasa, 1996), h. 1506

Tim Penyusun Undang-Undang Republik Indonesia, Tindak Pidana Suap, www.pih.deplu.go.id, diakses $17 / 02 / 2013$.

3 Departemen Agama Republik Indonesia, al-Quran dan Terjemahnya, (Semarang, CV. Syifa' Semarang: 1998), h. 23.

Rivai, Veithzal; Nuruddin, Amiur; Arfa, Faisar Ananda (2012) Islamic Business and Economic Ethics: Mengacu pada Al-Quran dan Mengikuti Jejak Rasulullah SAW dalam Bisnis, Keuangan, dan Ekonomi. Jakarta: Bumi Aksara

Chryssides GD, and Kaler JH. (1993) An Introduction to Business Ethics. London: Chapman and Hall Jones I, and Pollitt M. (1998) Introduction. In: Jones I, Pollitt M. (Ed.) The Role of Business Ethics in Economic Performance. London: MacMillan Press Grace D, and Cohen S. (1995) Business Ethics. Melbourne: Oxford University Press

Donaldson T. (1982). Constructing a Social Contract for Business. In: Donaldson T. (Ed.) Corporations and Morality. Englewood Cliffs: Prentice-Hall

Basah, MYA, and MM Yusuf. (2013) "Islamic Bank and Corporate Social Responsibility (CSR)." European Journal of Business and Management, 5 (11): 194-209. http://iiste.org/Journals/index.php/EJ BM/article/view/5441. Qardhawi, Yusuf. (2001) Peran Nilai dan Moral Dalam Perekonomian Islam. Jakarta: Rabbani Press. Naqvi SNH. (1981) Ethics and EconomicsAn Islamic Synthesis. Leicester: The Islamic Foundation. Haniffa, Oszaini; and Hudaib, Mohammad (2007) “Exploring the Ethical Identity of Islamic Banks via Communication in Annual Reports". Journal of Business Ethics,76:97-116.

Guza, Afnil (2008) Himpunan Undang-undang Perbankan Republik Indonesia, UU RI Nomor 21 Tahun 2008 Perbankan Syariah, UU RI nomor 10 Tahun 1998 Perbankan, UU RI Nomor 3 Tahun 2004 Bank Indonesia.Jakarta: Asa Mandiri 